\title{
Distribution, Growth and Food Habits of the Atlantic Wolffish (Anarhichas lupus) from the Gulf of Maine-Georges Bank Region
}

\author{
Gary A. Nelson and Michael R. Ross \\ Department of Forestry and Wildlife Management, 204 Holdsworth Hall \\ University of Massachusetts, Amherst, MA 01003, USA
}

\begin{abstract}
The spatial and temporal distribution patterns of the Atlantic wolffish (Anarhichas lupus) from the Gulf of Maine-Georges Bank region were examined based on bottom trawl survey data from 1963 to 1989. Age composition, growth and food habits were also evaluated from 1983 to 1989. Catches of wolffish were distributed throughout the region, but highest concentrations occurred along the $100 \mathrm{~m}$ depth contour of the Gulf of Maine-Georges Bank.

Statistical analyses of the depth occurrences revealed a seasonal shift in depth distribution from shallow water $(<120 \mathrm{~m})$ in spring to deeper water in autumn. Further analyses showed that the large $(>50 \mathrm{~cm})$ wolffish migrate to these shallow waters in spring and return to deeper waters in autumn.

The oldest wolffish aged was 22 years. Mean length-at-age ranged from $4.7 \mathrm{~cm}$ total length for age 0 to $98.0 \mathrm{~cm}$ total length for age 22 in spring. Growth was modelled best by the Gompertz function. Bivalve molluscs (primarily Placopecten magellanicus) dominated the diet, followed by echinoderms, gastropods and decapods.
\end{abstract}

\section{Introduction}

The Atlantic wolffish (Anarhichas lupus) is a commercially important, cold water species found on both sides of the North Atlantic. In the Northwest Atlantic, its distribution extends from off Greenland to the Nantucket Shoals off the eastern United States (Jonsson, 1982). It is typically captured incidental to fishing operations directed toward other benthic species in this region. Commercial landings in USA territorial waters are from the Gulf of Maine and Georges Bank (NAFO Subarea 5), where the total USA nominal catch increased from 200 tons in 1970 to 1200 tons in 1983 and have since declined to 500 tons (NMFS/NEFC, 1991). Additionally, National Marine Fisheries Service (NMFS), Northeast Fisheries Center, Woods Hole, Massachusetts, bottom trawl surveys indicate a long-term decline in relative abundance since the 1970s (NMFS/NEFC, 1991). Such information suggests that the Atlantic wolffish population of the Gulf of Maine-Georges Bank may be overexploited. However, currently there is no fishery management plan implemented to control fishing mortality on this species.

Data on population biology and dynamics of exploited species are essential for proper management strategies. Past research concerning the biology of the Atlantic wolffish has included studies on food habits (Jonsson, 1982; Albikovskaya, 1983; Templeman, 1985; Hawkins and Angus, 1986), dis- tribution and migratory patterns (Albikovskaya, 1982; Jonsson, 1982; Templeman, 1984), reproductive behaviour (Keats et al., 1985), age and growth (Jonsson, 1982) and sexual maturity and fecundity (Templeman, 1986) from Icelandic to Nova Scotian waters. Only descriptive data on depth distribution, food habits and breeding habits (Bigelow and Schroeder, 1953) are available for fishes in United States territorial waters. This study was undertaken to document trends in spatial and temporal distribution patterns based on bottom trawl survey data, and to evaluate quantitatively age, growth and food habits of Atlantic wolffish from the Gulf of MaineGeorges Bank region.

\section{Materials and Methods}

Data used for the spatial and temporal distribution analyses were collected from 1963 to 1989 in the Gulf of Maine-Georges Bank region by NMFS in a synoptic bottom trawl survey. The survey was based on a stratified-random sampling design for continental shelf waters $>27 \mathrm{~m}$ in depth, partitioned into strata of unequal area based on depth and geographic location (Grosslein, 1969; Azarovitz, 1981). Prior to 1968, sampling was conducted only in autumn. A spring survey was added to the annual schedule in 1968. Sampling effort was expanded in 1972 to include the nearshore waters between 5 and $27 \mathrm{~m}$ depth. Sampling during spring and autumn 
occurred generally in March to May and September to November, respectively.

Sampling stations were randomly selected within each stratum and effort (number of stations) allocated in rough proportion to stratum area. At each station, a \# 36 or \# 41 Yankee otter trawl with a 1.25 $\mathrm{cm}$ stretched mesh codend liner was towed at approximately 3.5 knots for $30 \mathrm{~min}$; bottom depth and near-bottom temperature data were also recorded (Azarovitz, 1981).

Changes in spatial distribution between spring and autumn were examined for the 1963-89 survey period. Depth of occurrences, weighted by the number of wolffish captured in each tow, were compared between seasons using Kruskal-Wallis nonparametric ANOVA (Gibbons, 1976). Further, length frequencies were examined by depth ranges for evidence of a seasonal reproductive migration noted by Keats et al. (1986). Due to the low numbers of wolffish captured annually, data from all survey years were combined for these analyses.

\section{Age and growth}

Wolffish were collected opportunistically for the age, growth and food habits analyses from autumn 1983 to spring 1989. Individuals captured in the otter trawl were weighed collectively to the nearest $0.1 \mathrm{~kg}$, measured individually (total length; TL) to the nearest $\mathrm{cm}$, and sexed. The head and entire digestive tract from the esophagus to rectal sphincter were then removed, stored in plastic bags, and frozen. Occasionally, small wolffish $(<30 \mathrm{~cm})$ were frozen whole.

In the laboratory, sagittal otoliths were excised from the heads, cleaned of extraneous tissue, and stored dry in coin envelopes. Age determination used similar techniques to those described by Jonsson (1982). One otolith (either left or right) was placed on black velvet to enhance hyaline zones, submerged in 50\% ethyl alcohol, and viewed under a binocular dissecting scope to 30X using reflected light. As Jonsson (1982) reported, otoliths from large wolffish can be very thick at the nucleus, thus hindering interpretation of the first few annuli. In order to expose the nucleus and innermost growth rings, we ground the region over the nucleus on the convex surface of such otoliths with fine grit sand paper until the central rings became clearly visible when viewed as described above.

An annulus was identified as a translucent hyaline ring that was preceded by a white opaque zone. Jonsson (1982) concluded the hyaline and opaque zones are formed in the winter and summer, respectively. In the age determination we independently counted the annuli from the nucleus out to the dorsal edge of the otolith, or from the nucleus to the distal edge of the subrostrum. If our first age estimates did not concur (28\% did not agree; age differences between the two readers were generally 1-2 years), we independently aged the otoliths a second time, then jointly examined the disputed otoliths until agreement was reached. A January 1 birthdate was assigned for all.

A total of 132 wolffish heads or whole fish were collected during the survey period from fish that ranged from 3.8 to $118 \mathrm{~cm} T L(X=61.5 \mathrm{~cm})$. Only 126 of those were used in age determination due to incomplete data records for the others. Due to the low numbers of age samples, growth was modelled by fitting mean lengths-at-age (years) for all years combined, weighted by the inverse variance, to the following functions:

Von Bertalanffy

$$
L_{t}=L_{\infty}\left(1-\exp ^{-k(\text { Age-to })}\right)
$$

Logistic

$$
L_{t}=L_{\infty} /\left(1+\exp ^{-k(\text { Age-to })}\right)
$$

Gompertz

$$
L_{t}=L_{\infty} \exp ^{-\exp ^{-k(\text { Age-to })}}
$$

Parameters $L_{\infty}, k$ and to were estimated using SAS nonlinear regression (Proc NLIN) with the optional derivative-free (DUD) method (SAS Institute, 1988). The goodness of fit of the assorted models was evaluated by comparing the magnitude of each model's weighted residual sum of squares. Age in years was designated with a 0 or 5 decimal extension that represented fish captured in spring and autumn, respectively.

\section{Food habits}

Contents of each digestive tract were identified to the lowest taxonomic level possible. The occurrence of each taxonomic group was recorded, and the frequency of occurrence (FREQ) of each taxonomic unit calculated as:

$$
\mathrm{FREQ}=\mathrm{n}_{\mathrm{i}} / \mathrm{n} \times 100
$$

where $\mathrm{n}_{\mathrm{i}}=$ number of stomachs containing taxo nomic unit i, and

$\mathrm{n}=$ total number of stomachs examined.

\section{Distribution}

\section{Results}

Catches were distributed uniformly throughout the Gulf of Maine basin (Fig. 1), but concentrations 


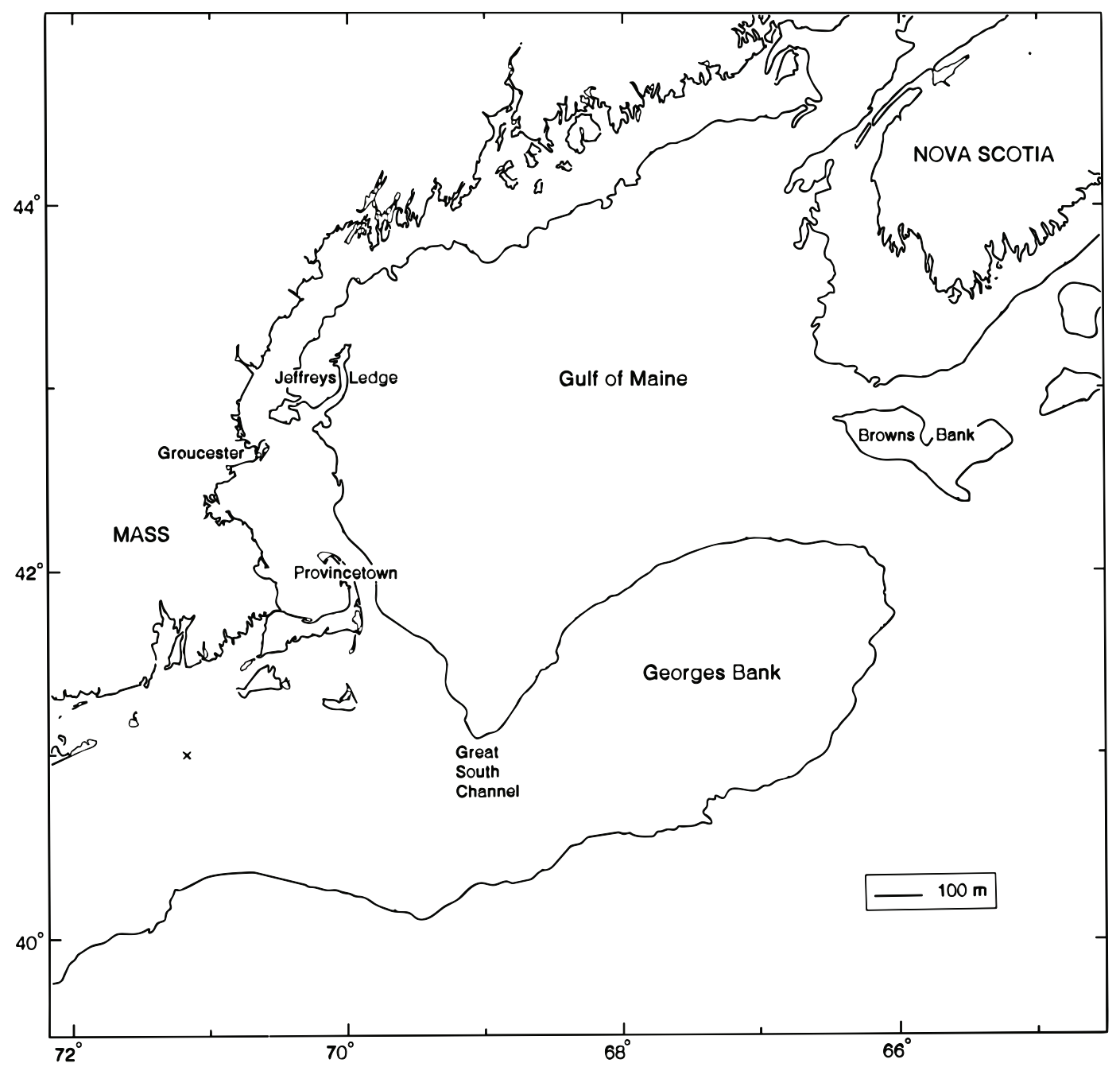

Fig. 1. Map of the Gulf of Maine, and Georges Bank and southern Nova Scotia area showing locations mentioned in the text. The $100 \mathrm{~m}$ depth contour is shown.

occurred at distinct areas along the $100 \mathrm{~m}$ depth contour from the northeast peak of Georges Bank to Jefferies' Ledge northeast of Gloucester, Massachusetts (Fig. 2). In spring, densities were highest on Browns Bank, the northeast peak of Georges Bank, along the Great South Channel and off slopes east of Provincetown and Gloucester, Massachusetts. Catches generally declined at all sites in autumn, except for the area east of Gloucester (Fig. 2).

Wolffish were captured in waters between 22 and $274 \mathrm{~m}$ deep. In spring, depth of occurrence ranged from 22 to $243 \mathrm{~m}(\overline{\mathrm{X}}=100.1, \mathrm{SD}=38.164$, mode $=80 \mathrm{~m})$, but were primarily $(75 \%)$ in depths $<120 \mathrm{~m}$ (Fig. 3). A weak shift in the depths of occurrence was evident in autumn as catch frequency increased in waters 90 to $130 \mathrm{~m}$ (range $=32$ to $274 \mathrm{~m}, \overline{\mathrm{X}}=102.6, \mathrm{SD}=34.60$, mode $=90 \mathrm{~m})(\mathrm{Fig}$. 3). Kruskal-Wallis ANOVA revealed significant differences between spring and autumn distributions $(\mathrm{KW}=7.97, \quad \mathrm{P}<0.01)$.

The length frequencies (Fig. 4 and 5) showed that wolffish segregate themselves by size with increasing depth. In spring, large wolffish $>50 \mathrm{~cm}$ comprised the largest proportion of the catches in waters $<120 \mathrm{~m}$, whereas fish $<50 \mathrm{~cm}$ increased in proportion as depth increased (Fig. 4). Wolffish $>50 \mathrm{~cm}$ comprised equal or slightly lower fractions of the autumn catches in waters $<120 \mathrm{~m}$, but fish $<50 \mathrm{~cm}$ were distributed similarly as in spring.

The preponderance of large wolffish in waters $<120 \mathrm{~m}$ during spring, and a subsequent decline of these individuals from the same depths in autumn, 


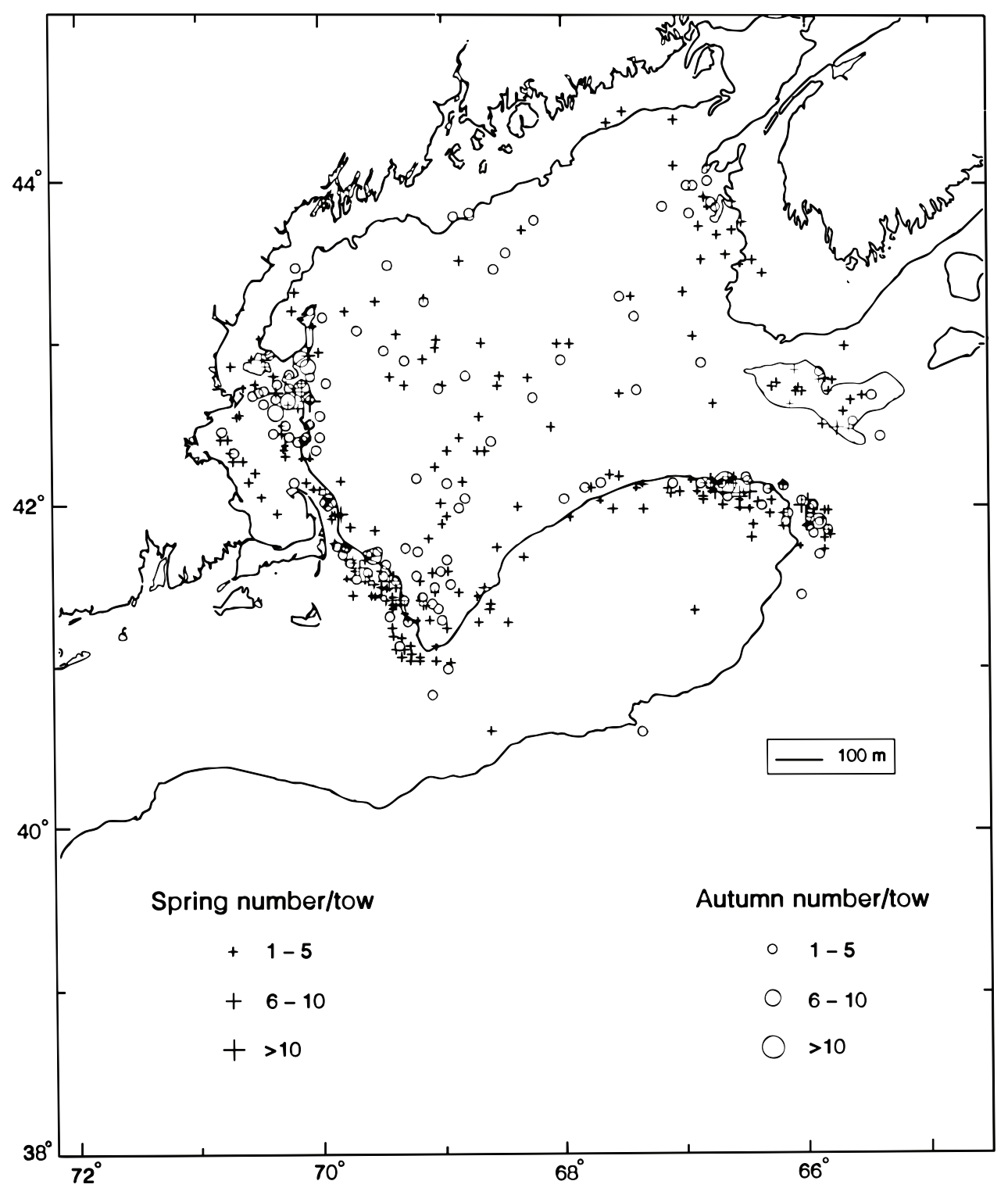

Fig. 2. Catch distribution of Anarhichas lupus in the Gulf of Maine-Georges Bank region during spring and autumn, 1963-89.

suggested they exhibit a seasonal inshore-offshore movement. To determine if this movement was temperature- or reproductively-related, we tested depth and temperature occurrence values of immature (<47 cm; Templeman, 1986) and mature (>47 $\mathrm{cm}$ ) wolffish for intra-seasonal differences using Kruskal-Wallis ANOVA. Means and standard deviations are listed in Table 1 for each group and season. Depth values between the immature and mature were significantly different $(\mathrm{KW}=130.62, \mathrm{P}$ $<0.001$ ) in spring only; the mature were more predominant in shallower water than immature individuals during this season. Differences were found for temperature in spring $(\mathrm{KW}=19.13, \mathrm{P}<0.001)$ and autumn ( $\mathrm{KW}=22.09, \mathrm{P}<0.01)$; the mature experienced colder temperatures in shallow water in spring, but slightly warmer temperatures than immature individuals during autumn. These results gave no support for a movement related to temperature, and thus, the movement was interpreted as more likely related to reproduction.

\section{Age and growth}

The oldest wolffish aged was 22 years. Mean lengths-at-age ranged from $4.7 \mathrm{~cm}$ TL for age 0 to $98.0 \mathrm{~cm}$ TL for age 22. No significant differences in mean length-at-age between sexes were found due 


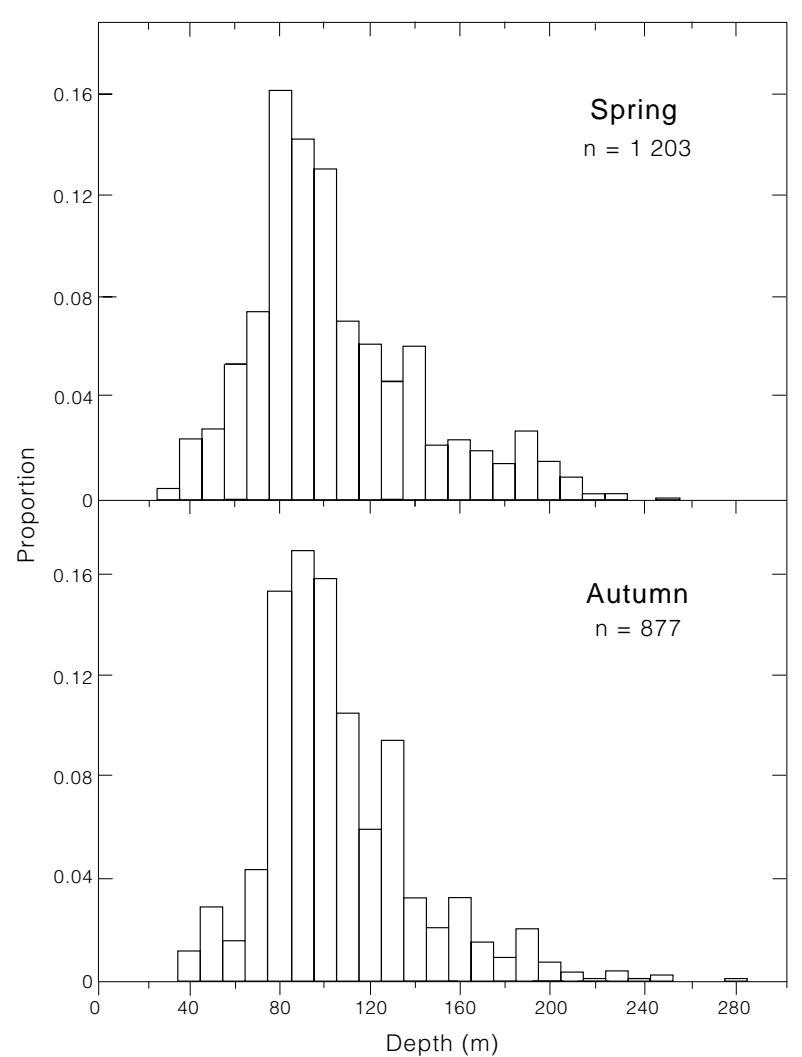

Fig. 3. Depth distributions of Anarhichas lupus from the Gulf of Maine-Georges Bank region in spring and autumn.

to our low sample size; thus, we combined data for both sexes for the subsequent growth analyses.

Of the nonlinear models utilized, growth was best described by the Gompertz equation (Fig. 6), as indicated by the lowest residual sum of squares (Table 2). Growth was very rapid for the first 4-6 years of life (average $5 \mathrm{~cm} /$ year), but decreased gradually thereafter. The asymptotic length $\left(L_{\infty}\right)$ derived for the Gompertz equation $(98.9 \mathrm{~cm}$ ) was lower than our observed maximum of $118 \mathrm{~cm}$, an under-estimate of $19.1 \mathrm{~cm}$. In comparison, the $L_{\infty}$ of the logistic model $(94.2 \mathrm{~cm})$ was also lower $(23.8$ $\mathrm{cm}$ ) than our observed maximum, but this parameter of the Von Bertalanffy model $(162.6 \mathrm{~cm})$ was much higher by a difference of $44.6 \mathrm{~cm}$. The imprecise estimates of the $L_{\infty}$ indicated that older fish were probably sampled inadequately, and there were probably too few data to successfully model growth; therefore, the growth analyses presented are preliminary at best.

\section{Food habits}

The majority of the wolffish (54 of 63) available for examination were taken in spring from the high

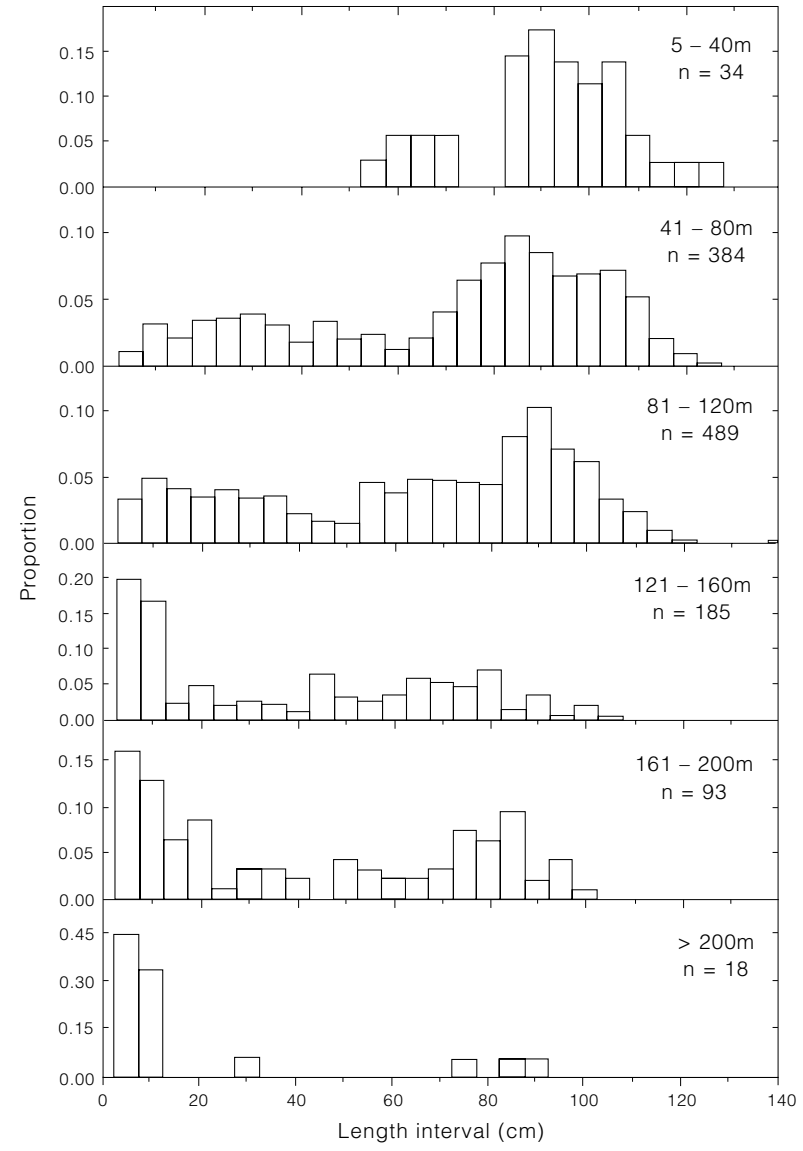

Fig. 4. Length frequency distributions of Anarhichas lupus captured in the NMFS bottom trawl survey during spring, 1963-89, by depth range.

density areas on northeast peak of Georges Bank and off Gloucester, Massachusetts, and ranged in length from 13 to $108 \mathrm{~cm}$. Two of the digestive tracts were empty. Table 3 presents a list of all food items with their corresponding frequency of occurrence. Gut contents represented four phyla (MolIusca, Arthropoda, Echinodermata and Chordata), six classes (Gastropoda, Bilvalvia, Malacostraca, Echinoidea, Stelleroidea and Osteichthyes) and 17 genera.

Of all diet items, bivalve molluscs occurred most frequently $(72.1 \%)$ in the digestive tracts (Table $3)$. The sea scallop was the most common bivalve (39.3\%), with four digestive tracts containing only this item. The Icelandic scallop (22.9\%), ocean quahaug (14.7\%), the "Arks" (9.8\%) and surf clam $(4.9 \%)$ were also found in tracts. Echinoids were secondarily dominant $(50.8 \%)$, and were represented principally by the green sea urchin (19.7\%) and sand dollar (8.2\%). Whelks (21.3\%) and Atlantic moon snails $(11.5 \%)$ were the most common gastropods. Hermit crabs (18.0\%) and Jonah crabs 
TABLE 1. Mean depth, mean temperature, and standard deviations (SD) for immature $(<47 \mathrm{~cm})$ and mature $(>47 \mathrm{~cm})$ Anarhichas lupus in spring and autumn ( $\mathrm{n}$ is the number sampled).

\begin{tabular}{|c|c|c|c|c|c|c|}
\hline & $\begin{array}{c}\text { Mean } \\
\text { deptha } \\
(\mathrm{m})\end{array}$ & \multicolumn{5}{|c|}{$\begin{array}{c}\text { Mean } \\
\text { temperature }\end{array}$} \\
\hline \multicolumn{7}{|c|}{ Spring } \\
\hline Immature & $116.3]^{b}$ & 39.08 & 437 & $5.07^{b}$ & 1.24 & 353 \\
\hline Mature & 90.8 & 34.37 & 766 & $4.6]$ & 1.23 & 608 \\
\hline \multicolumn{7}{|c|}{ Autumn } \\
\hline Immature & $102.5]^{c}$ & 31.46 & 537 & $7.3^{\mathrm{d}}$ & 1.83 & 492 \\
\hline Mature & 102.7 & 39.08 & 341 & 7.8 & 1.92 & 310 \\
\hline
\end{tabular}

\footnotetext{
a Distributions were compared using Kruskal-Wallis ANOVA.

b $\mathrm{P}<0.001$.

${ }^{\mathrm{C}}$ Not significant.

$d_{P}<0.01$.
}

TABLE 2. Estimated parameters and associated statistics of the Von Bertalanffy, logistic and Gompertz growth models for Anarhichas lupus from the Gulf of Maine-Georges Bank region. RSS = residual sum of squares.

\begin{tabular}{|c|c|c|c|c|}
\hline \multirow[b]{2}{*}{ Parameter } & \multirow[b]{2}{*}{ Estimate } & \multirow{2}{*}{$\begin{array}{l}\text { Asymptotic } \\
\text { Standard error }\end{array}$} & \multicolumn{2}{|c|}{$\begin{array}{c}\text { Asymptotic } 95 \% \\
\text { confidence }\end{array}$} \\
\hline & & & Lower & Upper \\
\hline \multicolumn{5}{|l|}{ Von Bertalanffy } \\
\hline$L_{\infty}$ & 162.60 & 22.239 & 116.70 & 208.54 \\
\hline K & 0.04 & 0.008 & 0.03 & 0.06 \\
\hline$t_{0}$ & -0.43 & 0.096 & -0.63 & -0.24 \\
\hline \multicolumn{5}{|c|}{ Weighted RSS $=47.756$} \\
\hline \multicolumn{5}{|l|}{ Logistic } \\
\hline$L_{\infty}$ & 94.21 & 2.697 & 88.64 & 99.77 \\
\hline K & 0.42 & 0.022 & 0.38 & 0.46 \\
\hline$t_{0}$ & 6.05 & 0.302 & 5.43 & 6.67 \\
\hline \multicolumn{5}{|c|}{ Weighted RSS $=44.141$} \\
\hline \multicolumn{5}{|l|}{ Gompertz } \\
\hline$L_{\infty}$ & 98.89 & 2.489 & 93.75 & 104.03 \\
\hline K & 0.22 & 0.011 & 0.20 & 0.24 \\
\hline$t_{0}$ & 4.74 & 0.221 & 4.28 & 5.19 \\
\hline \multicolumn{5}{|c|}{ Weighted RSS $=24.061$} \\
\hline
\end{tabular}

$(9.8 \%)$ were the dominant decapods. Brittle stars and fish eggs were of minor importance (Table 3).

\section{Distribution}

\section{Discussion}

Jonsson (1982) and Albikovskaya (1982) reported that the Atlantic wolffish is most abundant in depths 40 to $180 \mathrm{~m}$ in Iceland waters, and 101 to 350 $m$ in the Newfoundland area, respectively. In this study they were captured frequently in waters between 22 and $274 \mathrm{~m}$ in the Gulf of Maine-Georges Bank region. In addition, a weak shift in the depth distribution was noted as they moved from shallow water $(<120 \mathrm{~m})$ in spring to deeper water in autumn. We showed that this shift was related to larger, mature wolffish migrating inshore during spring. 
TABLE 3. Frequency of food items found in 61 stomachs of Anarhichas lupus from the Gulf of Maine-Georges Bank region.

\begin{tabular}{|c|c|c|}
\hline Phylum & Taxonomic unit & Frequency \\
\hline \multirow[t]{13}{*}{ Mollusca } & Gastropoda & 47.5 \\
\hline & Whelks (Buccinum sp.) & 21.3 \\
\hline & Atlantic moon snail (Polinices duplicatus) & 11.5 \\
\hline & Pygmy Colus (Colus pygmaeus) & 3.3 \\
\hline & Wentletrap (Epitonium sp.) & 1.6 \\
\hline & Northern moon snail (Lunatia heros) & 1.6 \\
\hline & Margarite top shell (Margarites sp.) & 1.6 \\
\hline & Bivalvia & 72.1 \\
\hline & Sea scallop (Placopecten magellanicus) & 39.3 \\
\hline & Islandic scallop (Chlamys islandicus) & 22.9 \\
\hline & Ocean quahaug (Arctica islandica) & 14.7 \\
\hline & Arks (Family Arcidae) & 9.8 \\
\hline & Surf clam (Spisula solidissima) & 4.9 \\
\hline \multirow[t]{6}{*}{ Arthropoda } & $\begin{array}{c}\text { Malacostraca } \\
\text { Decapoda }\end{array}$ & 44.3 \\
\hline & Hermit crabs (Pagurus sp.) & 18.0 \\
\hline & Jonah crabs (Cancer borealis) & 9.8 \\
\hline & Spider crabs (Libinia sp.) & 3.3 \\
\hline & American lobsters (Homarus americanus) & 1.6 \\
\hline & Northern shrimp (Pandalus borealis) & 1.6 \\
\hline \multirow[t]{4}{*}{ Echinodermata } & Echinoidea & 50.8 \\
\hline & Green sea urchin (Strongylocentrotus droebachiensis) & 19.7 \\
\hline & Sand dollar (Echinarachnius parma) & 8.2 \\
\hline & Stelleroidea (Brittle stars) & 1.6 \\
\hline Chordata & Osteichthyes (Fish eggs) & 1.6 \\
\hline \multicolumn{2}{|c|}{ Unidentifiable matter } & 3.3 \\
\hline
\end{tabular}

Jonsson (1982), Hawkins and Angus (1986) and Keats et al. (1986) noted similar movement patterns for Atlantic wolffish from Iceland, Nova Scotia and Newfoundland, respectively, and Keats et al. (1986) provided evidence that this migration is related to reproduction. Length frequencies also showed that small wolffish $(<50 \mathrm{~cm})$ were captured more frequently in deeper water than large individuals ( $>50$ $\mathrm{cm}$ ) in spring and autumn. Although lacking good evidence, Keats et al. (1986) hypothesized that young wolffish occupy deep water until they attain sexual maturity. Our results support their hypothesis.

\section{Age and growth}

Our study is the first to report age estimates for Northwest Atlantic wolffish. A. Iupus from the Gulf of Maine-Georges Bank apparently grow faster and reach a larger size-at-age than those from Iceland waters (Jonsson, 1982) (Fig. 7). Jonsson also reported males have a faster growth rate than females and are generally larger than females. We could not conclude this for fish from the study region because of our small sample size.

A Gompertz function predicted mean length-atage better than the Von Bertalanffy or logistic growth models. Although we concluded that there are too few data for older fish to propose the Gompertz as the best growth model, the exploited state of the population implies that representative samples may never be obtained for adequate modelling of the species' growth pattern. Therefore, our growth data may be the best available to fishery biologists and managers.

The inflection point of the Gompertz curve occurs at approximately the same length $(47 \mathrm{~cm})$ that wolffish from Labrador-Newfoundland region begin to mature (Templeman, 1986), suggesting the growth decrease is associated with a diversion of energy from somatic growth to gonadal development. At this length, wolffish from the Gulf of Maine-Georges Bank are 5-6 years old. 


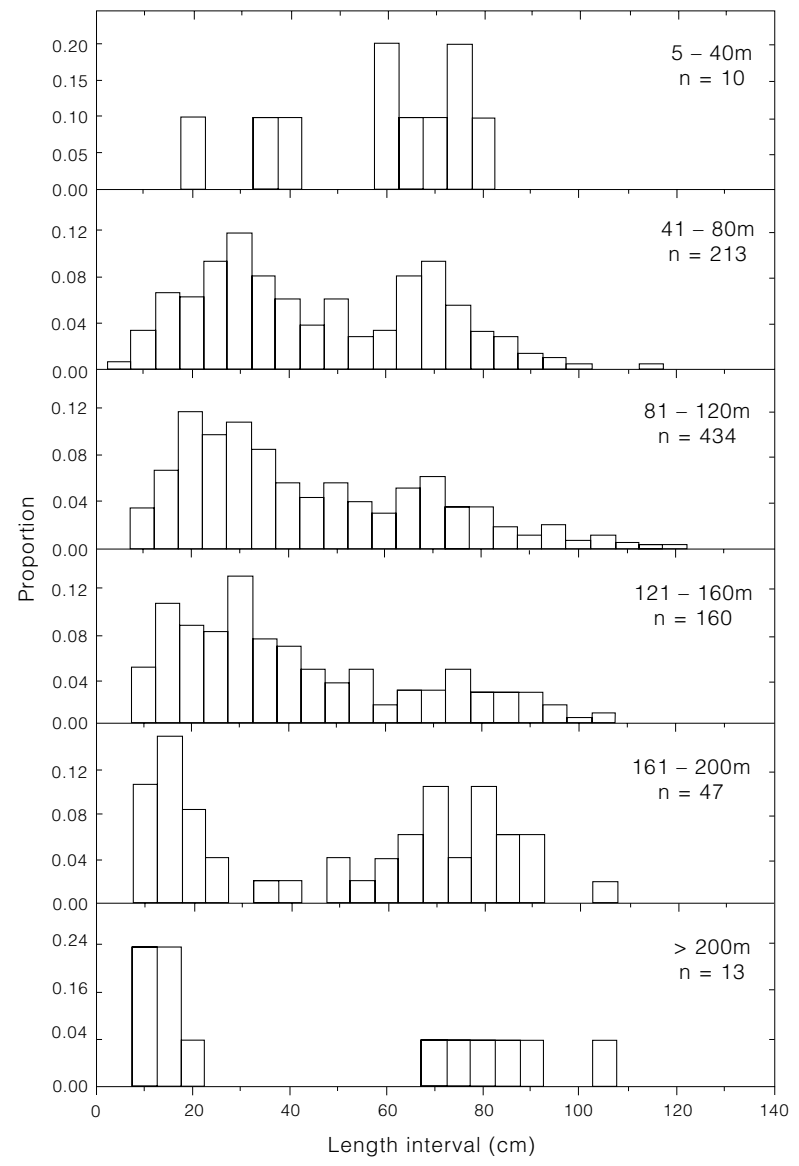

Fig. 5. Length frequency distributions of Anarhichas lupus captured in the NMFS bottom trawl survey during autumn, 1963-89, by depth range.

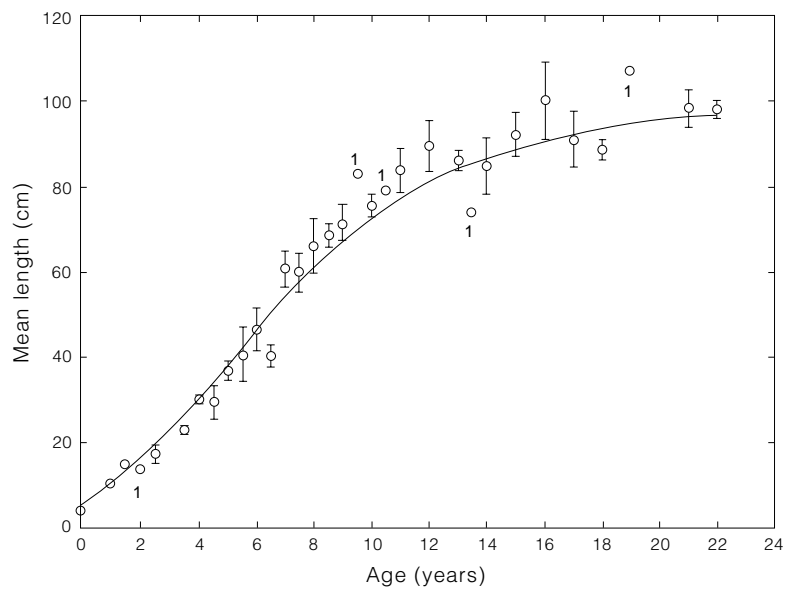

Fig. 6. Observed mean and predicted lengths-at-age of Anarhichas lupus from the Gulf of Maine-Georges Bank region. The predicted curve was fitted using a Gompertz function. The symbol "1" above or below a hollow dot represents the sample size for that age. Standard error bars are shown.

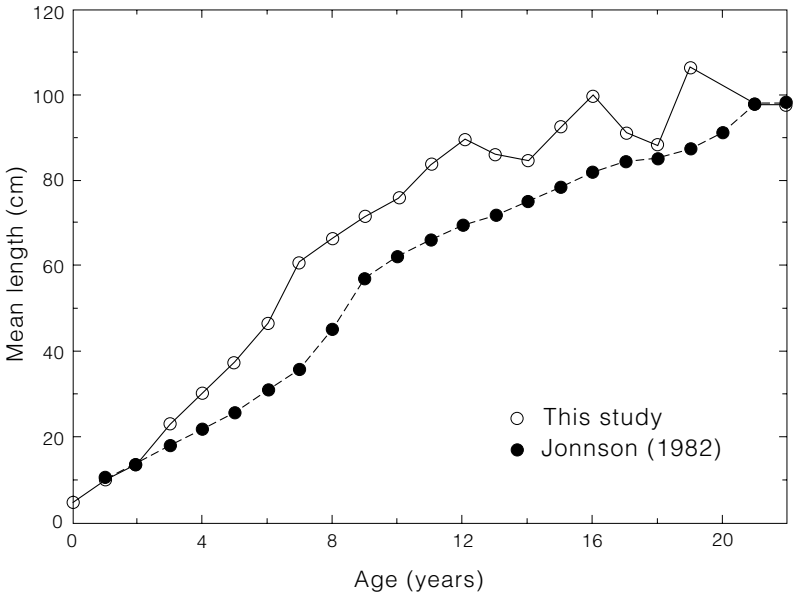

Fig. 7. Comparison of Anarhichas lupus mean lengthsat-age derived for the Gulf of Maine-Georges Bank region (this study) and Iceland waters (Jonsson, 1982). Only spring data from this study are shown.

\section{Food habits}

Albikovskaya (1983) and Templeman (1985) reported that Atlantic wolffish from the Scotian Shelf to Labrador-Greenland region feed primarily on benthic invertebrates. The diets of these fishes consisted mainly of gastropods (whelks), echinoderms (brittle stars, sea urchins and sand dollars), decapods (hermit crabs) and bivalve molluscs in decreasing frequency of occurrence. Our results were similar, but we found economically-important bivalves were predominant, followed by echinoderms, gastropods and decapods.

Given the predominance of bivalves in the diet, wolffish of Gulf of Maine-Georges Bank, could probably exert substantial predation pressure on bivalves in the study region. Hawkins and Angus (1986) reached this conclusion for inshore Nova Scotia waters, where ocean quahaugs were a major diet component. To truly assess the predatory impact of Atlantic wolffish on bivalves, more intensive studies are needed to quantify the co-occurring macroinvertebrate and wolffish abundances in the study region, as well as laboratory studies on selectivity and gastric evacuation rates. Given the importance of Gulf of Maine-Georges Bank bivalves to the economy of New England, such research is warranted.

\section{Acknowledgements}

The authors extend thanks to the scientists of the Northeast Fisheries Center and crew aboard the NOAA Albatross IV and Delaware II for collecting wolffish specimens. We especially thank J. M. Burnett for his relentless support to specimen 
collection during sea sampling. J. Pentilla provided initial assistance in age interpretation. S. Adams provided encouragement throughout the study. This study was funded in part by the UMASS/NOAA Cooperative Marine Education and Research Program (NOAA Cooperative Agreement NA89EAN00015).

\section{References}

AZAROVITZ, T. R. 1981. A brief historical review of the Woods Hole Laboratory trawl survey time series. In: Bottom Trawl Surveys. W. G. Doubleday and D. Rivard (eds.) . Can. Spec. Publ. Fish. Aquat. Sci., 58: 62-67.

ALBIKOVSKAYA, L. K. 1982. Distribution and abundances of Atlantic wolffish, spotted wolffish and northern wolffish in the Newfoundland area. NAFO Sci. Coun. Studies, 3: 29-32.

1983. Feeding characteristics of wolffishes in the Labrador-Newfoundland region. NAFO Sci. Coun. Studies, 6: 35-38.

BIGELOW, H. B., and W. C. SCHROEDER. 1953. Fishes of the Gulf of Maine. Fish. Bull. U.S., 53, 577 p.

GIBBONS, J. D. 1976. Nonparametric methods for quantitative analysis. Holt, Rinehart, and Winston, $463 \mathrm{p}$.

GROSSLEIN, M. D. 1969. Groundfish survey of the Bureau of Commercial Fisheries, Woods Hole. Com. Fish. Rev., 31(7): 22-25.
HAWKINS, C. M., and R. B. ANGUS. 1986. Preliminary observations of predation on ocean quahaugs, Arctica islandica, by Atlantic wolffish, Anarhichas lupus. The Naut., 100(4): 126-129.

JONSSON, G. 1982. Contribution to the biology of catfish (Anarhichas lupus) at Iceland. Rit. Fiskideild., 6(4): 3-26.

KEATS, D. W., G. R. SOUTH, and D. H. STEELE. 1985. Reproduction and egg guarding by Atlantic wolffish (Anarhichas lupus: Anarhichidae) and ocean pout (Macrozoarces americanus: Zoarcidae) in Newfoundland waters. Can. J. Zool., 63: 2565-2568.

1986. Where do juvenile Atlantic wolffish, Anarhichas lupus, live? Can. Field-Nat., 100(4): 556558.

NMFS/NEFC. 1991. Status of the Fishery Resources off the Northeastern United States for 1991. NOAA Tech. Mem., NMFS-F/NEC-86, $131 \mathrm{p}$.

SAS INSTITUTE. 1988. The NLIN Procedures. SAS/Stat User's Guide: Release 6.03 Edition, p. 675-712.

TEMPLEMAN, 1984. Migrations of wolffishes, Anarhichas sp., from tagging in the Newfoundland area. J. Northw. Atl. Fish. Sci., 5: 93-97.

1985. Stomach contents of Atlantic wolffish (Anarhichas lupus) from the Northwest Atlantic. NAFO Sci. Coun. Studies, 8: 49-51.

1986. Some biological aspects of Atlantic wolffish (Anarhichas lupus) in the Northwest Atlantic. J. Northw. Atl. Fish. Sci., 7: 57-65. 